\title{
INTERNALISASI ETIKA BIROKRASI DAN PENGUATAN SISTEM PENGENDALIAN SUMBER DAYA MANUSIA DALAM RANGKA MENCEGAH KORUPSI
}

\author{
Komang Adi Sastra Wijaya ${ }^{1}$ \\ Piers Andreas Noak ${ }^{2}$ \\ Program Studi Ilmu Administrasi Negara ${ }^{1}$ \\ Program Studi Ilmu Politik ${ }^{2}$ \\ Fakultas Ilmu Sosial dan Ilmu Politik \\ Universitas Udayana \\ Email : sastrawijaya@unud.ac.id
}

\begin{abstract}
ABSTRAK
Korupsi di Indonesia bukan hanya persoalan hukum atau sebuah penyimpangan perilaku. Lebih daripada itu, korupsi merupakan persoalan etika politik. Segala bentuk gratifikasi demi kepentingan pribadi merupakan sebuah bentuk korupsi. Dari sudut pandang etika birokrasi, korupsi berkembang karena kelemahan sistem penegakan hukum atauu kurangnya orientasi kepentingan publik baik dalam praktik maupun dalam kebijakan politik. Oleh karena itu, menguatkan internalisasi etika birokrasi menjadi cara yang paling efektif untuk mengatasi korupsi sampai ke akarnya. Etika politik yang dimaksud tidak dapat berjalan sendiri dan hanya mengedepankan kebebasan politik yang seringkali melindungi hak dan kepentingan pribadi, melainkan harus dibangun dan dikembangkan sejalan dengan demokratisasi. Lebih dari itu, korupsi harus diberantas dengan memperkuat etika politik kewarganegaraan, tanggung jawab kehidupan bernegara, semangat berkorban untuk negara, keadilan dan representasi sumber daya manusia dan pembentukan kepentingan publik serta penegakkannya dalam praktek politik dan determinasi kebijakan sebagai upaya dominan untuk mencegah korupsi.
\end{abstract}

Kata kunci: Etika Birokrasi, Sumber Daya Manusia, Pencegahan Korupsi

\begin{abstract}
Corruption in Indonesia is not only a matter of law or deviant behavior. But, more than that, it is a problem of political ethics. Any public use for the gratification of self-interest is a form of corruption. From bureaucratic ethics standpoint, corruption develops because the weaknesses of system reinforcement or lack of public interests formation in practice and political policy. Therefore, strengthening bureaucratic ethics internalization is the most effective way to overcome corruption from its roots. Such political ethics must be established and developed together with the ongoing democratization, not just to let it alone and only emphasizing the political freedom that often protect the rights and private interests. But, more than that, it must be eroded by strengthening the political ethics of citizenship, responsibility of life as a state, a sense of sacrifice for the country, equality and representation of human resources and public interest formation and its enforcement in political practice and policy determination as dominant effort to prevent corruption.
\end{abstract}

Keyword: Bureaucratic Ethics, Human Resources, Corruption Prevention 


\section{PENDAHULUAN}

Berbagai penyimpangan yang paling menghancurkan tatanan kehidupan bernegara saat ini adalah korupsi, yang pada umumnya dilakukan oleh mereka yang melaksanakan norma-norma dalam sistem pilitik atau mereka yang diluar pengecam oleh sistem itu yang ditumbuhkan oleh berbagai variasai transaksi pertukaran pada akhirnya menimbulkan kewajiban paling khas dipihak pemegang jabatan. Makin banyak transaksi pertukaran politis maka makin banyak penekanan moral etika pejabat dalam menentukan kebijakan publik sehingga timbulah berbagai kebijakan khusus yang lebih pada fariasi prototipe ekonomi yang berpijak pada kontrak secara tertutup pertukarannya.

Di Indonesia berbagai norma yang membatasi korupsi telah terintegrasi dengan budaya yang sulit menentukan batas kekuasaan dari pada penentukan kebijakan publik, sistem hukum yang melemah membuat pertukaran yang menyerupai korupsi lebih terjadi di kota kota besar yang tidak memerlukan perantara yang berpengaruh supaya tidak mendapat menfaat dari program perundanganundangan dan pemerintah.

Semua pihak semakin gelisah akan merajalelanya praktik korupsi dan kemudian ramai-ramai mencari solusi. Namun, solusi umum berkembang selama ini terlalu normatif. Karena berangkat dari asumsi bahwa masalah korupsi hanyalah masalah hukum. Asumsi dan pendekatan normatif tidak sepenuhnya akan efektif memberantas korupsi. Sudah terlalu banyak produk normatif untuk memberantas korupsi dihasilkan. Tetapi, di level empirik masih tetap menjadi-jadi. Meningkatnya produk normatif, tidak berbanding lurus dengan meredanya praktik tindak korupsi. Jika memang ingin mengatasi masalah korupsi secara tuntas harus dilihat secara komprehensif, tidak bisa secara parsial. Karena itu solusinya juga harus bersifat komprehensif internalisasi etika di birokrasi harus secara kultural maupun struktural.

Selama ini memberantas korupsi lebih banyak didekati dari normatif sehingga hanya menonjolkan pada masalah pemberian hukuman atau sanksi. Pada kenyataannya setelah sekian produk perundangan termasuk UU Anti Korupsi, tetapi praktik korupsi tetap saja marak. Bahkan setelah didirikan Komisi Pemberantasan Korupsi pun, meskipun harus diakui cukup mampu menekan dan membuat lebih hati-hati para pelaku korupsi, tetapi kasus-kasus tindak pidana korupsi tetap saja tinggi.

Ketika korupsi sudah menjadi perilaku budaya, seharusnya perlu dicarai solusi yang lebih menyeluruh dengan berbagai pendekatan. Memberantas korupsi perlu juga dari sosio-kultural, karena akar persoalannya memang lebih bersifat kultural. Kultural ini yang memberikan peluang birokrasi Weber sangat lemah dalam pengendalian melalui penerapan sistem patrimonial. Adanya 
penyimpangan etika birokrasi serta lemahnya pengendalian telah menjadikan korupsi itu sendiri dalam kenyataan bisa mengambil bentuk yang bermacam-macam, dari penyelewenganpenyelewengan jabatan secara halus dan tidak terasa oleh masyarakat luas sehingga pola-pola korupsi yang kasar dan sungguh tidak manusiawi. Pengaruh atau akibat dari korupsi pun tidak sama untuk setiap jenjang administrasi pemerintahan maupun untuk setiap negara. Akan tetapi, jika ditinjau dari sudut etika etis tidaknya sama yaitu penyalahgunaan kepercayaan dari orang banyak, dalam hal ini masyarakat atau para warga Negara. Sehingga bagaimana korupsi dilihat dari bagian penyimpangan etika birokrasi dan apakah dengan penguatan sistem pengendalian sumber daya manusia dapat mencegah korupsi ?

\section{ETIKA BIROKRASI DAN PENGUATAN SIKAP MENCEGAH KORUPSI}

Etika didefinisikan sebagai pemahaman tentang hal yang baik dan buruk atau hak dan kewajiban mengenai moral dan ahlak. Integritas adalah mutu, sifat atau keadaan yang menunjukkan kesatuan yang utuh sehingga memiliki potensi dan kemampuan yang memancarkan kewibawaan dan kejujuran jika keduanya digabung dan ditempatkan di dalam sanubari, maka dapat mencetak perilaku setiap individu untuk selalu beretika baik serta berintegritas tinggi baik di dalam maupun di luar lingkungan organisasi. Karena itu, etika birokrasi dan penguatan sistem pengendalian sumber daya manusia dalam rangka mencegah korupsi modalnya harus berani merumuskan integrasi keduanya ke dalam sebuah nilai etika berorganisasi.

Nilai etika harus dituangkan ke dalam berbagai aturan atau standar perilaku agar dapat menjadi kerangka perilaku yang dipedomani seluruh pegawai birokrasi. Nilai etika bukan sekadar bermanfaat untuk membentuk (memotivasi dan mendorong) perilaku pegawai sehari-hari, namun juga membimbing mereka ketika melakukan proses pengambilan keputusan. Sehingga jika nilai etika dapat ditegakkan secara konsisten dan konsekuen maka fondasi good governance di dalam organisasi akan semakin berdiri kokoh.

Korupsi berasal dari suatu kata dalam bahasa Inggris yaitu corrupt, yang berasal dari perpaduan dua kata dalam bahasa latin yaitu com yang berarti bersama-sama dan rumpere yang berarti pecah dan jebol. Menurut Bernardi (1994) istilah korupsi juga dapat diartikan sebagai suatu perbuatan tidak jujur atau penyelewengan yang dilakukan karena adanya suatu pemberian. Sementara Hermien H.K. (1994) mendefinisikan korupsi sebagai kekuasaan tanpa aturan hukum. Oleh karena itu, selalu ada praduga pemakaian kekuasaan untuk mencapai suatu tujuan selain tujuan yang tercantum dalam pelimpahan kekuasaan tersebut. Dalam konteks ekonomi korupsi 
mengandung pengertian penggunaan public office untuk keuntungan pribadi (Shleifer dan Vishny, 1993 dalam Riyanto 2008). Dalam konteks politik, Rose-Arkeman (2000) mengatakan bahwa korupsi merupakan gambaran hubungan antar negara dan sektor swasta. Kadang-kadang dalam hubungan tersebut pejabat negara yang menjadi pelaku dominan dan kadang-kadang pelaku swasta yang paling berkuasa. Kekuasaan tawar menawar relatif antara kelompok ini menentukan dampak keseluruhan korupsi terhadap masyarakat dan pembagian keuntungan antara penyuap dan yang disuap (Riyanto, 2008).

Demokratisasi telah mengubah birokrasi tidak lagi sebagai institusi tunduk pada kekuasaan politik otoritarian, atau otoritarian-patrimonialisme dalam konteks Orde Baru. Melainkan, kini lebih tunduk pada kekuasaan partai politik, atau lebih tepatnya oligarkhi partai dalam konteks patrimonialisme demokrasi yang masih berkembang sekarang. Birokrasi dibentuk sebenarnya untuk pelayanan publik berlandaskan pada prinsip rasional, objektif, dan profesional dalam pelayanan publik terlepas dari kekuasaan politik. Namun, birokrasi rasional semacam itu hanya tipe ideal. Akhir tahun 1990-an, bangsa Indonesia mampu menunjukkan sebagai bangsa yang mempunyai modal sosial untuk menjadi bangsa yang basar. Namun, kebanggaan tersebut masih dihantui oleh keraguan karena perilaku korupsi yang terjadi di masa demokratisasi itu tidak kalah merusaknya dibandingkan dengan korupsi pada masa kekuasaan yang represif. Sementara jika kita menengok ke beberapa negara-negara yang dikenal sebagai negera otoriter atau semi otoriter lebih bisa menikmati kemakmuran.

Wajah perubahan birokrasi yang diakibatkan oleh adanya demokratisasi telah membanggakan Indonesia, ditengah masa krisis politik pada masa transisi kekuasaan

Dalam konteks Indonesia, budaya politik patrimonial sangat kuat mempengaruhi birokrasi sebagai warisan kultur birokrasi kolonial dan patrimonial di masa lalu. Korupsi berkembang karena kuatnya demokrasi patrimonial ini yang menyamakan kekuasaan politik dengan kelembagaan birokrasi dan lebih berorientasi pada pelayanan kepada penguasa atasan daripada kepentingan publik. Reformasi birokrasi harus dilakukan untuk mengikis korupsi bersifat kultural politik ini. Oleh karena itu, kerja birokrasi haruslah menjadi bagian dari berkerjanya sistem demokrasi berpijak pada keterwakilan kepentingan publik dan supermasi hukum dan kesetaraan hak setiap warga negara mendapat pelayanan birokrasi yang baik. Kultur demokrasi disini perlu dikembangkan dalam kerja birokrasi, agar tidak terjebak pada patrimonialisme dan oligarkhi politik, dan juga bukan semata hanya mengikuti logika organisasi atau korporasi, tetapi lebih mengikuti logika demokrasi berpijak pada kepentingan atau keterwakilan publik dalam pengambilan dan pelaksaaan kebijakan publik. 
Birokrasi di Malaysia lebih diorientasikan ke bisnis untuk menggantikan peran aktif birokrasi dalam pembangunan dan meredefinisi perannya sebagai fasilitator dalam aktivitas sektor swasta. Dalam kasus di Thailand, munculnya peran birokrasi publik adalah untuk memfasilitasi kebijakan pro-pasar seperti privatisasi dan berbagai aktivitas yang berkaitan dengan sektor swasta seperti business licensing, perdagangan internasional, dan pengawasan fiskal. Perubahan birokrasi di Thailand belakangan ini juga lebih menempatkan dirinya sebagai katalisator untuk memfasilitasi aktivitas ekonomi yang civil service-nya berperan sebagai pendukung dan bukannya pemimpin (Wertheim, W.F. 1977).

Hal yang sama juga dilakukan Filipina. Hal ini dengan jelas menunjukkan bahwa perubahan birokrasi itu menekankan perlunya keterbukaan struktural untuk memungkinkan terjadinya pertukaran gagasan dan perubahan inovasi. Meski demikian, tidak semua negara berhasil melakukan perubahan birokrasi. Singapura dan Malaysia tergolong cukup efektif mewujudkan beberapa reformasi administrasi, antara lain karena stabilitas politik dan kerja sama yang baik antara birokrasi dan pemimpin politik. Sementara itu, Indonesia, Thailand, dan Filipina kurang efektif dalam mewujudkan perubahan administrasi karena dominannya aparat birokrasi dan adanya konflik atau kolusi antara birokrasi dan elite politik.

Saat ini, Indonesia menduduki tingkat korupsi tertinggi di dunia. Tingkat korupsi ini, dibuktikan dari hasil yang dilakukan Transparency International (TI). Indonesia menempati angka 2,8 dengan rangking 110 dari 178 negara pada tahun 2010 dan angka 2,8 dengan rangking 110 dari 180 negara terkorup pada tahun 2011. Sedangkan Political and Economic Risk Consultantcy Ltd (PERC), menempatkan Indonesia sebagai negara terkorup di Asia yang berada di bawah Vietnam dan Filipina. Dengan tingkat korupsi 8,32 pada tahun 2010 dan 9,10 pada tahun 2011.

Jika kita lihat fakta kenyataan yang ada, memang tak dipungkiri lagi. Korupsi, terkesan sudah mendarah daging dan bagaikan sesuatu yang tak dapat dipisahkan bagi penyelengara negara. Katakanlah badan atau lembaga apa yang kurang di negeri ini untuk mengatasi dan mencegah tindakan korupsi. Bahkan, lembaga pengawasan berlapis pun tak mampu membendungnya. Di internal kelembagaan, ada inspektorat yang mengawasi, BPK, BPKP, yang lebih luas ada KPK, serta lembaga-lembaga lainnya di eksternal kelembagaan yang terus menerus mengobarkan semangat anti korupsi. Namun, kenyataan dilapangan lembaga-lembaga tersebut belum mampu mengatasi korupsi yang begitu tinggi. Keberadaan partai politik pun terkesan menjadi bagian dari rantai korupsi. 
Melihat kemerosotan nilai-nilai kebangsaan seperti diatas, maka korupsi harus dibendung dengan penekanan norma dalam dimensi etika organisasi Pemerintah, yang antara lain mencakup etika dalam organisasi, etika dalam pemerintahan, etika dalam jabatan, serta nilai-nilai kepemerintahan yang baik (good governance) sebagai trend global etika pemerintahan. Bagi aparatur pemerintah, budaya dan etika kerja merupakan hal yang penting untuk dikembangkan baik pada tingkat pemerintahan pusat maupun daerah, pada tingkat Departemen atau organisasi maupun unitunit kerja dibawahnya. Adanya etika ini diharapkan birokrasi sebagai organisasi rasional mampu membangkitkan kepekaannya (pemerintah) dalam melayani kepentingan masyarakat (Nicholas Henry, dalam Zakarya, 2012).

\section{PENGUATAN SISTEM PENGENDALIAN SDM DAN PENCEGAHAN KORUPSI}

Dalam dua dekade terakhir, dunia mulai memandang korupsi sebagai isu penting. Berbagai insiatif untuk mencegah korupsi dilakukan mulai dari tingkat nasional, regional hingga level internasional. Korupsi dipandang bukan hanya sebagai permasalahan moral dan penyimpangan etika belaka tetapi sebagai permasalahan multidimensional yang merupakan masalah politik, ekonomi, sosial dan budaya. Mental priyayi, feodalisme, paternalisme yang merupakan pengejewantahan budaya birokrasi patrimonial yang berlandaskan pada unsur klientisme, kaburnya wilayah publik dan privat, dan kultur non rasional yang menyebabkan pemicu terjadinya berbagai praktek bad governance, karena pimpinan dan birokrat menjadi tidak akuntabel dan tidak transparan dalam mengelola kebijakan publik dan yang akirnya memicu korupsi dan perilaku rent seeking lainnya.

Bentuk yang paling sederhana dari munculnya perilaku rent seeking tersebut terlihat dari pembentukan daerah-daerah administrasi baru (pemekaran wilayah) yang hanya berorientasi pada kekuasaan dan jabatan pemerintah yang baru. Dalam bentuk yang kompleks, munculnya jejaringan rente didaerah, terlihat dari pertarungan-pertarungan antar kepentingan kelompok di daerah dalam merebut kekuasaan. Pola-pola perterungan kepentingan tersebut makin kompleks, terutama disebabkan juga oleh relasi antar proses-proses pemilihan kepala daerah, proses interaksi antara DPRD dan Kepala daerah, dan proses-proses pengambilan keputusan poilitik strategis yang dilakukan oleh parpol-parpol. Parpol yang tidak memiliki platform yang sesuai dengan pola pembangunan dan kesejahteraan rakyat secara serius, disamping kecendrungan yang terjadi adalah parties formulate policies in order to win election, rather than win election in order to formulate policies,(Teufik F. Nas, Albert C. Price dan Charles T. Weber (1996). 
Korupsi di Indonesia benar-benar sangat sistemik, bahkan korupsi yang terjadi sudah berubah menjadi vampir state karena hampir semua infra dan supra struktur politik dan sistem ketatanegaraan sudah terkena penyakit korupsi. Agenda pemberantasan korupsi sampai detik ini hanyalah dijadikan komoditas politik bagi elit politik, lebih banyak pada penghancuran karakter (character assasination) bagi elit yang terindikasikan korupsi dibanding pada proses hukum yang fair dan adil. Law enforcement bagi koruptor juga menjadi angin lalu, padahal tindakan korupsi yang dilakukan koruptor sangatlah merugikan rakyat, Klitgaard dalam Masduki (2002).

Fenomena korupsi tersebut diatas menurut Baswir (1996) pada dasarnya berakar pada bertahannya jenis birokrasi patrimonial di negeri ini. Dalam birokrasi ini, dilakukannya korupsi oleh para birokrat memang sulit dihindari. Sebab kendali politik terhadap kekuasaan dan birokrasi memang sangat terbatas. Penyebab lainnya karena sangat kuatnya pengaruh integralisme di dalam filsafat kenegaraan bangsa ini, sehingga cenderung masih mentabukan sikap oposisi. Karakteristik negara kita yang merupakan birokrasi patrimonial dan negara hegemonik tersebut menyebabkan lemahnya fungsi pengawasan, sehingga merebaklah budaya korupsi itu.

Menurut Susanto (2001) korupsi pada level pemerintahan daerah adalah dari sisi penerimaan, pemerasan uang suap, pemberian perlindungan, pencurian barang-barang publik untuk kepentingan pribadi. Sementara tipe korupsi menurut de Asis (2000) adalah korupsi politik, misalnya perilaku curang (politik uang) pada pemilihan anggota legislatif ataupun pejabat-pejabat eksekutif, dana ilegal untuk pembiayaan kampanye, penyelesaian konflik parlemen melalui cara-cara ilegal dan teknik lobi yang menyimpang). Tipe korupsi yang terakhir yaitu clientelism (pola hubungan langganan).

Baswir (1993) menjelaskan ada 7 pola korupsi yang sering dilakukan oleh oknum-oknum pelaku tindak korupsi baik daari kalangan pemerintah maupun swasta. Ketujuh pola tersebut meliputi : (1) pola konvensional, (2) pola upeti, (2) pola komisi, (4) pola menjegal order, (5) pola perusahaan rekanan, (6) pola kuitansi fiktif dan (7) pola penyalahgunaan wewenang. Untuk menanggulangi terjadinya korupsi yang bermacam-macam jenisnya ini diperlukan strategi khusus dari semua bidang, meskipun untuk menghilangkan sama sekali praktik korupsi adalah sesuatu yang mustahil, tertapi setidaknya-tidaknya ada upaya untuk menekan terjadinya tindak korupsi. Strategi yang dibentuk hendaknya melibatkan seluruh lapisaan masyarakat dan pejabat struktur pemerintahan dengan memperbaiki sumber daya manusia bermartabat dan bermoral sesuai etika dan ideologi bangsa.

Sementara menurut Mochtar Lubis dalam Fadjar (2002) pola terjadinya korupsi dapat dibedakan dalam tiga wilayah besar yaitu , Pertama, bentuk penyalahgunaan kewenangan yang berdampak terjadinya korupsi adalah pertama; Mercenery abuse of power, penyalahgunaan 
wewenang yang dilakukan oleh orang yang mempunyai suatu kewenangan tertentu yang bekerjasama dengan pihak lain dengan cara sogok-menyogok, suap, mengurangi standar spesifikasi atau volume dan penggelembungan dana (mark up). Penyalahgunaan wewenang tipe seperti ini adalah biasanya non politis dan dilakukan oleh level pejabat yang tidak terlalu tinggi kedudukannya.

Kedua, Discretinery abuse of power, pada tipe ini penyalahgunaan wewenang yang dilakukan oleh pejabat yang mempunyai kewenangan istimewa dengan mengeluarkan kebijakan tertentu misalnya keputusan Walikota/Bupati atau berbentuk peraturan daerah/keputusan Walikota/Bupati yang biasanya menjadikan mereka dapat bekerjasama dengan kawan/kelompok (despotis) maupun dengan keluarganya (nepotis).

Ketiga, Idiological abuse of power, hal ini dilakukan oleh pejabat untuk mengejar tujuan dan kepentingan tertentu dari kelompok atau partainya. Bisa juga terjadi dukungan kelompok pada pihak tertentu untuk menduduki jabatan strategis di birokrasi/lembaga ekskutif, dimana kelak mereka akan mendapatkan kompensasi dari tindakannya itu, hal ini yang sering disebut politik balas budi yang licik. Korupsi jenis inilah yang sangat berbahaya, karena dengan praktek ini semua elemen yang mendukung telah mendapatkan kompensasi.

Jika kita merujuk Gustavo Gutiérrez Merino dalam Wijayanto (2005), yang menitik beratkan pada penanaman nilai-nilai etika dalam menjalankan birokrasi. Dirinya, menjelaskan bahwa pendidikan anti-korupsi mengharuskan adanya tiga langkah. Pertama, pembebasan politik dan sosial yang mengukuhkan tindak korupsi. Kedua, emansipasi dan partisipasi seluruh masyarakat sebagai korban tindak korupsi untuk membenci dan mengalienasi para koruptor. Ketiga, pembebasan dari egoisme dan dosa dengan mendekatkan Tuhan ke bumi. Etika yang menjunjung tinggi nilai ketuhanan dalam bertingkah laku didalam menjalankan amanah rakyat. Penanaman etika ini menjadikan sasaran terciptanya sebuah keadilan didalam masyarakat, dengan adanya batasan pemisahan antara penegakan hukum dan kepentingan politik.

Penegakkan hukum dan norma dalam membangun integritas birokrasi memerlukan waktu dan kesungguhan yang dimulai dengan penerapan integritas secara individual dari para birokrat yang kemudian akan menjadi sebuah kebiasaan/perilaku berintegritas dan pada akhirnya akan menjadikan integritas sebagai a way life. Apabila seorang pemimpin birokrasi telah dapat menjadikan integritas sebagai a way life maka ia menjadi teladan bagi orang-orang yang dipimpinnya. Dan dalam konteks mencegah korupsi, tindakan tersebut sangat diperlukan oleh para pemimpin birokrasi agar dapat menjaga instansi dan orang-orang yang dipimpinnya terhindar dari praktek korupsi yang merugikan negara dan masyarakat. 
Dari pernyataan tersebut, dapat kita ambil sebuah manfaat membangun etika birokrasi dan penguatan sistem pengendalian sumber daya manusia dalam rangka mencegah korupsi di Indonesia. Penanaman etika ini bertujuan agar tindakan korupsi tidak dijadikan warisan budaya bangsa. Pemikiran ini, merupakan sebuah langkah yang tepat untuk memperbaiki negeri ini, dalam memerangi korupsi. Jika penanaman etika ini terbentuk, penulis harapkan terciptanya penegakan hukum dan kesejahteraan bagi rakyat. Korupsi yang terjadi selama ini, telah menghancuran sendisendi kehidupan, bukan hanya sebatas perekonomian semata, tetapi mampu merubah budaya yang ada di masyarakat.

\section{SIMPULAN}

Kurangnya internalisasi etika dan moral justru membuka peluang besar terjadinya deviasi moral akibat hilangnya integritas pribadi para birokrat. Ketiadaan integritas pribadi membuat para birokrat begitu mudah melanggar janji jabatannya serta kewajiban-kewajiban dasarnya, dan mengingkari kejujuran dalam pekerjaannya. Kekosongan integritas ini justru membuat mereka kehilangan orientasi makna. Mereka tidak mampu menghubungkan visi dengan praktik hidupnya serta tidak mampu lagi membaca tanda-tanda zaman. Akibatnya, mereka tidak bisa menyingkap segisegi yang bermakna dari suatu kasus untuk bisa mengambil keputusan dengan tepat.

Disamping gagasan otonomi daerah dimana kewenangan ekonomi dan kekuasaan cukup besar yang kemudian berkombinasi dengan faktor buada paternalistik feodalistik serta integralistik telah menyuburkan tipe masyarakt kultur yang tumbuh dengan nyaman dalam pola primordialisme, komunalisme, kanibalisme yang masih kokoh telah menyulitkan demokratisasi berperan secara adil dalam memberikan ruang gerak masyarakat secara keseluruhan untuk bisa mengawal proses pemerintahan yang bebas dari korupsi tersebut. Untuk itu diperlukan tindakan pencegahan yang harus merubah budaya yang sehat kedalam struktur pemerintah yang demokratis tanpa memihak pada pola primordoal yang ada.

Beberapa tindakan pencegahan korupsi yang perlu mendapat perhatian serius adalah pembentukan integritas bangsa, penerapan good governance dan pelaksanaan reformasi birokrasi. Dari ketiga dimensi tersebut, yang paling krusial dilaksanakan adalah pembentukan integritas bangsa karena sifatnya lebih kepada intangible action dibandingkan dengan penerapan good governance dan reformasi birokrasi. Pembentukan integritas bangsa harus dimulai dari seorang pemimpin, terutama para pemimpin lembaga publik yang menerima mandat dari rakyat untuk menjalankan penyelenggaraan pemerintahan negara. 
Melakukan pembenahan terhadap struktur pemerintah negara dan struktur insentive birokrasi berupa rewards (besaran dalam struktur gaji pegawai) yang tidak jauh dengan besaran gaji perusahaan hingga bisa menjamin kehidupan yang layak bagi pegawai birokrasi, disamping itu juga harus diikuti juga dengan sistem penalty (punishment) bagi yang tidak disipli serta kinerjanya buruk.

Bisa saja hal itu karena nilai etika yang diakibatkan oleh penyimpangan mungkin dicanangkan berlaku dengan sangat normatif dan tidak implementatif. Atau bisa pula hanya menjadi propaganda legal-formal pemerintah yang sekadar menciptakan citra positif aparaturnya ke tengah masyarakat. Yang pasti memang belum pernah ada upaya serius pemerintah dalam melakukan internalisasi nilai etika kepada aparaturnya birokrasi meningkatkan sumber daya manusia sehingga dapat berlaku dan dipatuhi secara konsisten memberantas korupsi di lembaga birokrasi.

\section{Referensi}

Andi, Hamzah. 2007, Pemberantasan Korupsi Melalui Hukum Pidana Nasional Dan Internasional. Jakarta : PT. Grafindo Persada

Bull, Martin J and James L. Newell eds. 2003. Corruption in Contemporary Politics, New York: Palgrave Macmillan.

Desta, Yemane. 2006. Designing Anti-Corruption Strategies for Developing Countries: A Country Study of Eritrea. Journal of Developing societies, Vol. 22 No. 4.

Ferdiansyah, Ferry. 2010. Membudayakan Etika, Melawan Korupsi.

Haryatmoko, 2011. Etika Publik untuk Integritas Pejabat Publik dan Politisi. Jakarta : Gramedia Pustaka Utama

Syafiie, Inu Kencana. 1999. Ilmu Administrsai Publik, Jakarta : Rineka Cipta.

Isworo, Waluyo Iman.2007. Akuntabilitas, Responsibilitas, dan Etika dalam Administrasi Publik. Jurnal Ilmu Administrasi dan Organisasi, Bisnis \& Birokrasi, Vol. 15, No. 1 (Januari)

Kumorotomo, Wahyudi. 2009. Etika Administrasi Negara. Jakarta : PT. Rajawali Pers

Lubis, Mochtar dan James Scott, 1993. Korupsi Politik. Jakarta : Yayasan Obor Indonesia

Lubis, Mochtar. 1977. Bunga Rampai Etika Pegawai Negeri. Jakarta: Bhratara Karya Aksara

Margono, Subando Agus. "Demoralisasi Birokrasi dan Manipulasi Kebijakan Publik: Telaah Pengembangan Kapasitas Untuk Mencermati Lemahnya Governance", dalam Wahyudi Kumorotomo dan Ambar Widaningrum (ed.). 2010. Reformasi Aparatur Negara Ditinjau Kembali. Penerbit Gava Media dan Jurusan Manajemen dan Kebijakan Publik dan Magister Administrasi Publik UGM, Yogyakarta.

Ndaraha, Taliziuduhu, 2002. Kybernology (Ilmu Pemerintahan Baru). Jakarta : Rineka Cipta 
Nugroho, Riant. 2011. Public Policy. Jakarta : Gramedia

Riyanto, Gunarsa Isang, Fauzi Ahmad dan Darmawan Arya Hadi, 2008. Jurnal Ekonomi dan Pembangunan Indonesia. Vol. VIII No. 02, 2008 Januari. Korupsi dalam Pembangunan Wilayah, Suatu Kajian ekonomi Politik dan Budaya, jakarta.

Syed Husen Alatas, 1987. Korupsi : Sifat, Sebab dan Fungsi. Jakarta : LP3ES

Teufik F. Nas; Albert C. Price dan Charles T. Weber. 1996. A Policy-Oriented Theory of Corruption. The American Political Science Review, Vol 80, No.1. page: 109

Yahya Zakaria dan Paulus Israwan Setyoko, 2011. Pelibatan Masyarakat Sebagai Etika Dalam Formulasi Kebijakan Publik Guna Mencegah Praktik Korupsi, Makalah Simposium Nasional Asosiasi Ilmuwan Administrasi Negara (SIMNAS ASIAN) ke-2 di Universitas Slamet Riyadi, Surakarta , pada tanggal 10 Pebruari 2012.

Wertheim, W.F. 1977. Segi-Segi Sosiologi Korupsi di Asia Tenggara . Oxford : Oxford University Press

Wijayanto. "Memahami Korupsi", dalam Wijayanto dan Ridwan Zachrie (ed.). 2005. Korupsi Mengorupsi Indonesia. Jakarta : Gramedia 
